\title{
AT1 Receptor Antagonist Candesartan Attenuates Genomic Damage in Peripheral Blood Lymphocytes of Patients on Maintenance Hemodialysis Treatment
}

\author{
Nicole Schupp ${ }^{a}$ Przemyslaw Rutkowski ${ }^{e} \quad$ Katarina Šebekováf ${ }^{f}$ André Klassen ${ }^{c}$

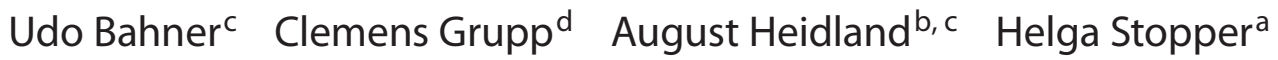 \\ anstitute of Pharmacology and Toxicology and bepartment of Internal Medicine, University of Würzburg, \\ 'Kuratorium for Dialysis and Kidney Transplantation, Würzburg, and d Center of Internal Medicine, Bamberg, \\ Germany; ${ }^{\text {DDepartment }}$ of Nephrology, Transplantology and Internal Medicine, Medical University of Gdansk, \\ Gdansk, Poland; ' Slovak Medical University Bratislava, Bratislava, Slovakia
}

\section{Key Words}

Genomic damage • Micronuclei · Angiotensin II •

AT1 antagonists

\begin{abstract}
Background: Angiotensin II (ANG II) and advanced glycation end products (AGEs) exert genotoxic effects in vitro which were prevented by the ANG II type 1 (AT1) receptor blocker, candesartan. In end-stage renal disease (ESRD) the incidence of genomic damage is increased. A stimulation of the reninangiotensin system and accumulation of AGEs could be involved. Methods: We tested whether oral co-administration of candesartan modulates enhanced DNA damage in ESRD patients. Fifteen maintenance hemodialysis (MHD) patients with mild hypertension were treated with candesartan for 4.5 months. Fourteen MHD patients served as conventionally treated uremic controls. DNA damage was measured as micronucleus frequency (MNF) in peripheral blood lymphocytes and evaluated three times before candesartan therapy and afterwards every 6 weeks. Results: Compared to 14 healthy controls, MNF at baseline was significantly elevated in MHD patients. While in the conventionally treated MHD patients the enhanced DNA damage persisted, the co-administration of candesartan ameliorated the genomic damage significantly and independently of blood pressure
\end{abstract}

changes. Conclusion: Blockade of AT1 receptors with candesartan can reduce DNA damage in MHD patients. Long-term studies in larger patient groups are needed to investigate whether the improved genomic damage lowers atherosclerotic complications and cancer development.

Copyright $\odot 2011$ S. Karger AG, Basel

\section{Introduction}

In end-stage renal disease (ESRD) genomic damage is enhanced, as shown in peripheral blood lymphocytes (PBLs) by the micronucleus (MN) frequency (MNF) test and the single cell gel electrophoresis-comet assay (CA) [1-3], elevated 8-hydroxy-deoxyguanosine concentrations in white blood cells [4], sister chromatid exchanges, chromosomal aberrations $[5,6]$ and mitochondrial DNA deletions $[7,8]$. Unrepaired or improperly repaired DNA lesions may have serious consequences, such as premature ageing $[9,10]$, atherosclerosis $[11,12]$ and cancer predisposition $[13,14]$. Recently, cohort studies have shown a correlation between the frequency of structural chromosomal aberrations or micronuclei in PBLs and an en-

N.S. and P.R. contributed equally to this study.

\section{KARGER}

Fax +4161306 1234 E-Mail karger@karger.ch www.karger.com
(C) 2011 S. Karger AG, Basel

$1420-4096 / 11 / 0343-0167 \$ 38.00 / 0$

Accessible online at:

www.karger.com/kbr
Dr. Nicole Schupp

Institute of Pharmacology and Toxicology, University of Würzburg

Versbacher Strasse 9

DE-97078 Würzburg (Germany)

Tel. +49931 201 48722, E-Mail nicole.schupp@ toxi.uni-wuerzburg.de 
Table 1. Baseline characteristics of the MHD patients, with and without candesartan treatment

\begin{tabular}{lcc}
\hline & $\begin{array}{c}\text { Candesartan- } \\
\text { treated MHD } \\
(\mathrm{n}=15)\end{array}$ & $\begin{array}{l}\text { Conventionally } \\
\text { treated MHD } \\
(\mathrm{n}=14)\end{array}$ \\
\hline Age, years & $63.8 \pm 14.6$ & $68.5 \pm 10.1$ \\
Range, years & $29-83$ & $52-82$ \\
Male/female & $10 / 5$ & $7 / 7$ \\
Time on MHD, years & $6.2 \pm 4.1$ & $7.7 \pm 5.8$ \\
Systolic BP, mm Hg & $148 \pm 9$ & $136 \pm 24$ \\
Diastolic BP, mm Hg & $81 \pm 11$ & $71 \pm 15$ \\
\hline Cause of end-stage renal disease & & \\
Glomerulonephritis & 7 & 6 \\
Hypertensive nephropathy & 4 & 3 \\
Pyelonephritis & 1 & 3 \\
Diabetic nephropathy & 1 & 1 \\
Polycystic kidney disease & 0 & 1 \\
Unknown & 2 & \\
\hline Antihypertensive drug treatment & & 2 \\
B-Blocker & 8 & 5 \\
Calcium channel antagonists & 5 & \\
Central antihypertensive & 3 & \\
Loop diuretics & 5 & \\
\hline
\end{tabular}

hanced cancer occurrence $[15,16]$. In patients with coronary artery disease, a positive relationship between micronuclei levels and the severity of the atherosclerotic lesions was found [17]. In ESRD patients, the incidence of cancer $[18,19]$ and cardiovascular disease $[20]$ is tremendously increased, and the presence of genomic damage in these patients could play a decisive role in the development of these disturbances.

Among the mechanisms of DNA damage and a depressed DNA repair in ESRD [21], numerous factors could be involved, such as formation of reactive oxygen species in the presence of a reduced antioxidative defense mechanism [22] and hypomethylation [23]. Besides the uremic state, the pro-oxidative effect of hemodialysis treatment as well as iron infusion contribute to the observed genotoxicity $[24,25]$. The dialysis-induced DNA damage is associated with an enhanced spontaneous DNA repair [26]. Recently, genotoxic effects of various advanced glycation end products (AGEs) as well as of angiotensin II (ANG II) in mammalian cells have been demonstrated, which could be suppressed by both AT1 blockade and antioxidants [27-29]. We hypothesized that the enhanced genomic damage in ESRD patients could be, at least in part, a consequence of an activated AT1 receptor, since the administration of an ACE inhibitor/AT1 receptor blocker has been shown to combat the oxidative stress in hypertensive patients [30-32] and to reduce the morbidity/mortality in maintenance hemodialysis (MHD) patients [33, 34]. To elucidate the potential involvement of AT1 receptors on DNA damage in ESRD patients, we studied the effect of chronic co-administration of the AT1 receptor antagonist, candesartan, in mildly hypertensive patients on MHD therapy. The results obtained demonstrate a significant improvement, suggesting the involvement of AT1 receptors in the pathogenesis of genomic damage in ESRD.

\section{Methods}

The study was carried out in accordance with the Declaration of Helsinki and approved by the Ethics Committee of the Medical Faculty of the University of Würzburg. All patients gave their written informed consent prior to participation in this prospective, non-randomized, clinical pilot study.

Subjects

A total of 29 MHD patients (characteristics and antihypertensive treatment are given in table 1) were recruited: 15 stable ESRD mildly hypertensive patients on MHD, without previous treatment with AT1 blockers and/or ACE inhibitors for at least 3 months, were enrolled for the active treatment. The remaining 14 MHD patients served as conventionally treated (i.e. not treated with candesartan) controls, and an additional 14 healthy subjects (7 male/7 female, age $53.4 \pm 13.2$ years, range $36-79$ ) as controls for the baseline MNF. The age difference between the healthy controls and the treated MHD patients was statistically not significant. Patients with acute or chronic infections as well as carcinomas or congestive heart failure were excluded.

The dialysis was performed with synthetic biocompatible noncomplement-activating polysulfone membranes (FX60 dialyzer; Fresenius Medical Care, Bad Homburg, Germany). The adequacy of dialysis was measured by the urea reduction ratio $(>65 \%)$ and $\mathrm{Kt} / \mathrm{V}(>1.2)$ values. DNA damage was evaluated using the MN frequency test in PBLs, three times before start of the study and three times during treatment with candesartan in 6-week intervals. The candesartan doses were prescribed according to the individual BP measurement with the intention to adjust it to upper normal levels. In dialysis patients, lower levels of BP are associated with a high risk of hypotension as a consequence of volume contraction during dialysis treatment. The BP was measured immediately before and during the hemodialysis sessions. The candesartan doses ranged between 4 and $16 \mathrm{mg} /$ day with a low average level of $8.8 \mathrm{mg} /$ day. The total treatment period lasted 4.5 months.

\section{Blood Sampling}

Venous blood samples were taken in the morning before start of dialysis, after a 2-day weekend break. Nine milliliters of whole blood was collected into heparinized containers (Sarstedt, Nümbrecht, Germany). The lymphocyte isolation started within $4 \mathrm{~h}$. After the first centrifugation, the plasma was transferred to $1-\mathrm{ml}$ tubes and stored at $-80^{\circ} \mathrm{C}$ for further analyses. 


\section{Blood Chemical Analysis}

Routine chemistry [such as electrolytes, creatinine (Cr), urea, total protein (TP), albumin (Alb), and C-reactive protein (CRP)] was analyzed employing Vitros 250 analyzer (J\&J, Rochester, N.J., USA) before and after 3 and 4.5 months of treatment.

\section{Lymphocyte Isolation and Cultivation}

PBLs were isolated from whole blood via gradient centrifugation (Histopaque 1077; Sigma Diagnostics, St. Louis, Mo., USA), washed twice with RPMI 1640 medium (Sigma-Aldrich, Taufkirchen, Germany) and resuspended in RPMI 1640 medium supplemented with $15 \%$ FCS, $1 \%$ L-glutamine, $1 \%$ Na-pyruvate, $1 \%$ MEM non-essential amino acid solution and penicillin/streptomycin. The PBLs were cultured at $37^{\circ} \mathrm{C}$ in a humidified atmosphere containing $5 \% \mathrm{CO}_{2}$.

\section{Micronucleus Frequency}

$\mathrm{MN}$ are expressed in dividing cells that either contain chromosome breaks (resulting from unrepaired double-strand breaks) or by whole chromosomes that are unable to travel to the spindle poles during mitosis. They are observed in cells with completed nuclear division and are counted in the binucleated stage of the cell cycle after using the cytokinesis inhibitor cytochalasin B. This test was carried out as described by Fenech [35] with slight modifications. During the treatment period, cytochalasin B $(5 \mu \mathrm{g} / \mathrm{ml}$ final concentration) was added to obtain binucleated cells. Human PBLs were cultured with phytohemagglutinin at a concentration of $5 \mu \mathrm{g} / \mathrm{ml}$ in order to stimulate the cells to enter the cell cycle. After $44 \mathrm{~h}$, cytochalasin B was added. Following an additional $20 \mathrm{~h}$ of cultivation, cells were transferred to glass slides by cytospin centrifugation and fixed with methanol $\left(-20^{\circ} \mathrm{C}, 1 \mathrm{~h}\right)$. For staining binucleated cells, the slides were incubated with acridine orange $(62.5 \mu \mathrm{g} / \mathrm{ml}$ in Sorensen buffer, $\mathrm{pH}$ 6.8) for $5 \mathrm{~min}$, washed twice with Sørensen buffer for $5 \mathrm{~min}$ and mounted for microscopy. The incidence of MN was obtained after scoring 1,000 binucleated cells per slide, with each data point representing the mean from 3 slides. In addition, the percentage of binucleated cells was evaluated as a cell proliferation marker. All counting of $\mathrm{MN}$ during the study was performed by the same person.

\section{Statistics}

Results are expressed as mean \pm SEM. ANOVA with post-hoc Bonferroni was used to detect differences between groups. The Wilcoxon signed-rank test was used to analyze the development of parameters in matched groups. ANOVA with replication and post-hoc Bonferroni was used to evaluate differences in parameters observed over time. Statistical significance was defined starting at $\mathrm{p} \leq 0.05$.

\section{Results}

Co-administration of candesartan resulted in a nonsignificant trend to lower BP values (table 2). There was no clear dose-dependent effect of candesartan; even a low dose of $4 \mathrm{mg} /$ day decreased the systolic BP. In the conventionally treated MHD patients no change of BP during the time span of the study was observed (table 2).
Table 2. BP values and laboratory parameter before and after candesartan treatment

\begin{tabular}{llcc}
\hline & & $\begin{array}{l}\text { Candesartan- } \\
\text { treated MHD } \\
(\mathrm{n}=15)\end{array}$ & $\begin{array}{l}\text { Conventionally } \\
\text { treated MHD } \\
(\mathrm{n}=14)\end{array}$ \\
\hline Systolic BP, mm Hg & before & $148 \pm 9$ & $136 \pm 24$ \\
& after & $141 \pm 9$ & $132 \pm 24$ \\
\hline Diastolic BP, mm Hg & before & $81 \pm 11$ & $71 \pm 15$ \\
& after & $78 \pm 10$ & $70 \pm 12$ \\
\hline Serum creatinine & before & $11.1 \pm 2.8$ & $8.9 \pm 2.0^{\#}$ \\
& after & $11.4 \pm 2.4$ & $8.9 \pm 1.8^{\#}$ \\
\hline Serum urea, mg/dl & before & $143 \pm 20$ & $120 \pm 24$ \\
& after & $137 \pm 14$ & $127 \pm 22$ \\
\hline Potassium level, mmol/l & before & $5.1 \pm 0.7$ & $5.3 \pm 0.7$ \\
& after & $5.2 \pm 0.4$ & $5.3 \pm 0.6$ \\
\hline Albumin & before & $36 \pm 3$ & $39 \pm 2$ \\
concentration, g/l & after & $37 \pm 2$ & $39 \pm 3$ \\
\hline Total protein, g/l & before & $59 \pm 5$ & $60 \pm 8$ \\
& after & $59 \pm 5$ & $61 \pm 6$ \\
\hline CRP, mg/l & before & $16.3 \pm 10.6$ & $13.0 \pm 10.9$ \\
& after & $16.9 \pm 9.6$ & $18.8 \pm 16.0^{*}$ \\
\hline
\end{tabular}

${ }^{*} \mathrm{p}<0.05$ vs. baseline.

${ }^{\#} \mathrm{p}<0.05$ vs. candesartan-treated MHD patients.

No changes in concentrations of serum creatinine, albumin or total protein were observed in either group throughout the treatment (table 2). The plasma concentration of potassium tended to increase in the candesartan-administered patients, while in those on conventional treatment it remained unchanged. In the treated group, the CRP levels did not change, while in the conventionally treated MHD patients, CRP rose significantly (table 2).

\section{Micronuclei Frequency in Peripheral Blood \\ Lymphocytes}

When compared to the healthy controls, the MNF was significantly higher before the start of the study in both MHD groups (fig. 1). Co-administration of candesartan ameliorated the degree of genomic damage by $27.7 \%(\mathrm{p}=$ 0.01 ), while in the conventionally treated MHD controls the damage persisted.

The time course of the genomic damage in the candesartan-treated and conventionally treated groups is given in figure 2. Evidently, the beneficial effect of candesartan manifested itself already during the first 6 weeks of treatment and continued to persist over the whole study period. 


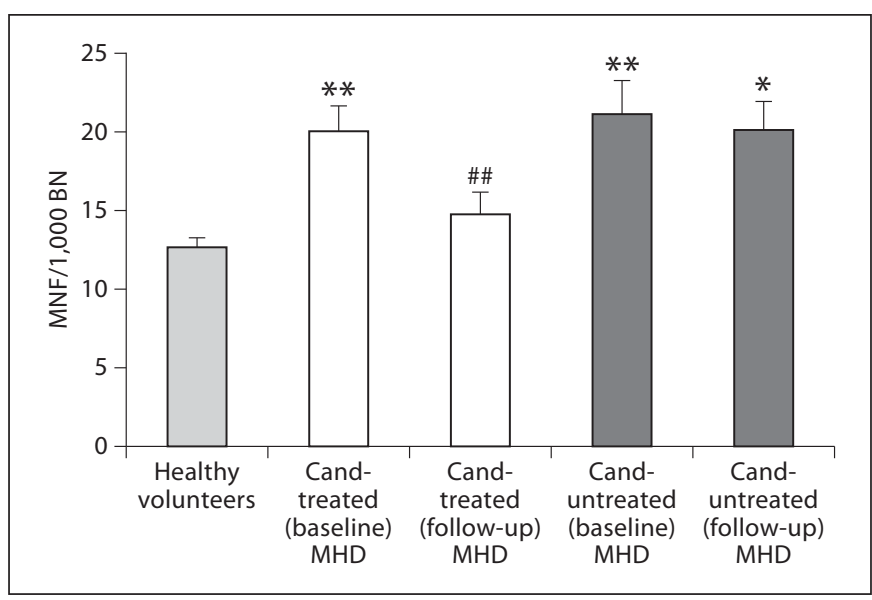

Fig. 1. $\mathrm{MNF} / 1,000$ binucleated $(\mathrm{BN})$ cells in healthy volunteers $(\mathrm{n}=14)$ and in the candesartan (Cand)-treated $(\mathrm{n}=15)$ and -untreated $(n=14)$ groups of MHD patients. ${ }^{*} \mathrm{p}<0.05,{ }^{* *} \mathrm{p}<0.01$ vs. healthy volunteers; ${ }^{\# \#} \mathrm{p}<0.01$ vs. Cand-treated MHD patients.

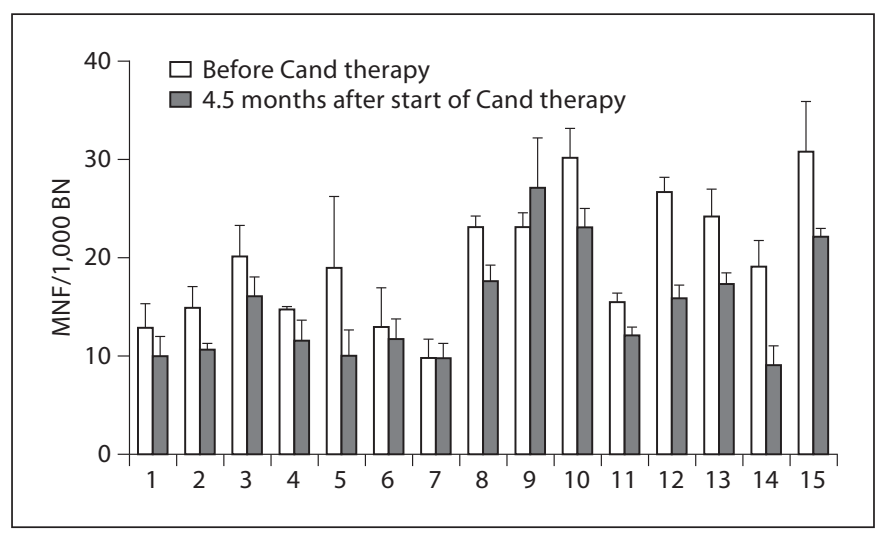

Fig. 3. $\mathrm{MNF} / 1,000$ binucleated $(\mathrm{BN})$ cells before and after 4.5 months of candesartan (Cand) therapy. Mean values of 3 measurement time-points before and after therapy in the individual patients $(\mathrm{n}=15)$.

The individual data (mean values) of the MNF before and after candesartan treatment are presented in figure 3. In 11 of the 15 patients, a decline of MNF could be observed. The positive response was related to the baseline degree of $\mathrm{MN}$, i.e. in the presence of highest micronuclei frequency levels the treatment effect was more pronounced. The lowering of $\mathrm{MN}$ was not related to the change of BP or the proinflammatory markers.

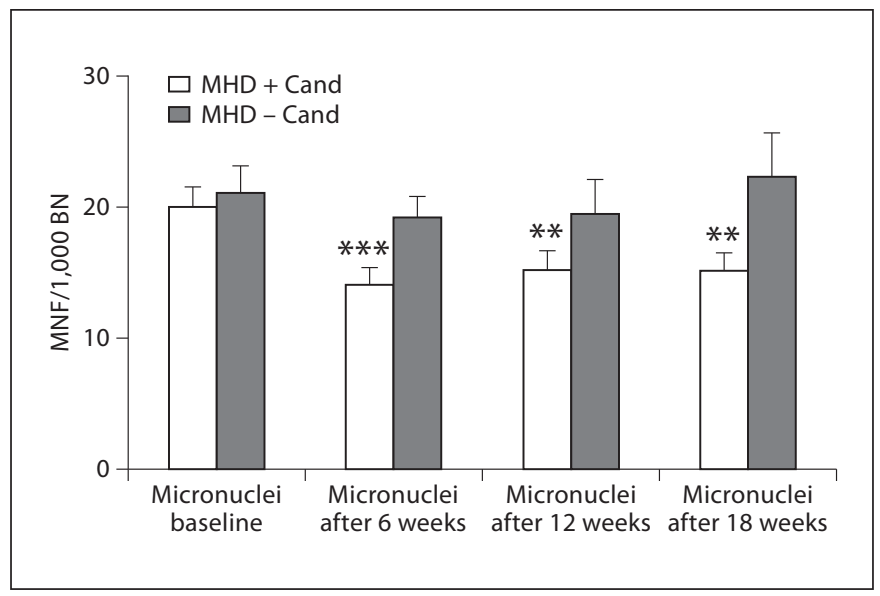

Fig. 2. Time course of $M N F / 1,000$ binucleated (BN) cells in the MHD groups treated and untreated with candesartan (Cand). Values are shown after 6,12 and 18 weeks. ${ }^{* *} \mathrm{p}<0.01,{ }^{* * *} \mathrm{p}<$ 0.001 vs. micronuclei baseline of Cand-treated MHD patients.

\section{Discussion}

Various therapeutic interventions improved the genomic damage in ESRD, e.g. co-administration of vitamin E [36], benfotiamine [37], folic acid and vitamin $B_{12}$ [38] resulted in a significant decline of micronuclei frequency. Moreover, daily dialysis was associated with less genomic damage [39].

In the current study, co-administration of candesartan for 4.5 months was reflected by a significant decline of the MNF, while in the conventionally treated MHD patients no change of DNA damage occurred. The beneficial effect was independent of BP changes. The decline of the BP was insignificant. This was due to the fact that the pretreatment values were only slightly elevated while the treatment target of $\mathrm{BP}$ values was in the upper normal range to prevent any dialysis-induced hypotension. The reduced micronuclei frequency in the candesartan-treated group suggests that an activated AT1 receptor is involved in the development of genomic damage in ESRD. The fact that ANG II exerts genotoxic effects via the AT1 receptor has been documented by our group in various mammalian cells [29], as well as in the perfused mouse kidney [40]. In addition, the marked accumulation of AGEs in ESRD could contribute to an activation of the AT1 receptor, as demonstrated in our in vitro studies with various AGEs [27-29]. The lowering of DNA damage by candesartan is most probably a consequence of a decline of intracellular oxidative stress following a diminished activation of 
NADPH oxidase. In our study no measurements of intracellular oxidative stress parameters were performed, but administration of enalapril to hemodialyzed patients resulted in the improvement of antioxidative defense [32]. In the present study the extracellular marker of inflammation, the acute phase reactant - CRP concentration remained unchanged in the candesartan-treated group. However, in the untreated patients there was a significant rise of CRP. These results suggest an anti-inflammatory action of candesartan in our patients. A more pronounced anti-inflammatory action has been observed in patients with essential hypertension [41, 42], diabetics [43], or hypercholesterolemic volunteers [44]. However in these investigations the candesartan doses were much higher and up to $32 \mathrm{mg} /$ day in contrast to our investigations with an average dose of $8.8 \mathrm{mg} /$ day.

In the past it was shown that DNA damage plays a critical role in the mechanisms of atherosclerosis $[11,12]$ and cancer development $[13,14]$. Long-term studies in larger patient groups are needed to evaluate whether the improved genomic damage observed in our study contributes to a decline in cardiovascular complications and cancer incidence. Interestingly, it was demonstrated that administration of the AT1 receptor blocker, candesartan, as well as of various ACE inhibitors in MHD patients resulted in a significant lowering of morbidity and mortality $[33,34]$. However, a recent meta-analysis reported other findings in MHD patients: although treatment with ACE inhibitors or angiotensin receptor blockers reduced left ventricular mass, they were unable to reduce fatal and non-fatal cardiovascular events significantly [45].

It remains to be clarified whether the high incidence of cancer in MHD patients $[18,19]$ may be lowered by a long-term renin-angiotensin system blockade. In a crosssectional study in hypertensive patients without renal failure, long-term use of ACE inhibitors was shown to protect against cancer development [46]. However, in elderly hypertensive patients (mean age 76 years) a longitudinal, prospective study over a treatment period of about 5 years did not show any difference in cancer risk between patients assigned to conventional antihypertensive therapy or to ACE inhibitors [47]. To our knowledge, no data are available about a long-term effect of AT1 blockade on cancer risk.

Summarizing our data shows a BP-independent improvement of genomic damage in peripheral lymphocytes in MHD patients after co-administration of the AT1 receptor blocker, candesartan, for 4.5 months. If these alterations are representative of other tissues and the cardiovascular system, in the long run the lowered genomic damage could lead to beneficial effects of reninangiotensin system blockade on morbidity and mortality in MHD patients.

\section{Acknowledgements}

We thank Maria Scheurich for excellent technical assistance and AstraZeneca for supporting us with candesartan. The project was supported by AstraZeneca (Wedel, Germany) and the Verein zur Bekämpfung der Hochdruck- und Nierenkrankheiten Würzburg e.V. (Germany).

\section{Disclosure Statement}

The Verein zur Bekämpfung der Hochdruck- und Nierenkrankheiten Würzburg e.V. (Germany, Chairman Prof. Dr. August Heidland) has received financial support from AstraZeneca (Wedel, Germany). Dr. Schupp, Dr. Rutkowski, Dr. Šebeková, Dipl.-Psych. Klassen, Prof. Dr. Bahner, Dr. Grupp and Prof. Dr. Stopper declare no potential conflicts of interest.

\section{References}

- 1 Stopper H, Meysen T, Bockenforde A, Bahner U, Heidland A, Vamvakas S: Increased genomic damage in lymphocytes of patients before and after long-term maintenance hemodialysis therapy. Am J Kidney Dis 1999; 34:433-437.

-2 Stopper H, Boullay F, Heidland A, Vienken J, Bahner U: Comet-assay analysis identifies genomic damage in lymphocytes of uremic patients. Am J Kidney Dis 2001;38:296-301.

-3 Stoyanova E, Sandoval SB, Zuniga LA, El-Yamani N, Coll E, Pastor S, Reyes J, Andres E, Ballarin J, Xamena N, Marcos R: Oxidative DNA damage in chronic renal failure patients. Nephrol Dial Transplant 2010;25:879-885.
-4 Tarng DC, Huang TP, Wei YH, Liu TY, Chen HW, Wen Chen T, Yang WC: 8-Hydroxy2'deoxyguanosine of leukocyte DNA as a marker of oxidative stress in chronic hemodialysis patients. Am J Kidney Dis 2000;36: 934-944.

5 Cengiz K, Block AM, Hossfeld DK, Anthone R, Anthone S, Sandberg AA: Sister chromatid exchange and chromosome abnormalities in uremic patients. Cancer Genet Cytogenet 1988;36:55-67.

6 Buemi M, Floccari F, Costa C, Caccamo C Belghity N, Campo S, Pernice F, Bonvissuto G, Coppolino G, Barilla A, Criseo M, Crasci E, Nostro L, Arena A: Dialysis-related geno- toxicity: sister chromatid exchanges and DNA lesions in T and B lymphocytes of uremic patients. Genomic damage in patients on hemodiafiltration. Blood Purif 2006;24: 569-574.

7 Lim PS, Ma YS, Cheng YM, Chai H, Lee CF, Chen TL, Wei YH: Mitochondrial DNA mutations and oxidative damage in skeletal muscle of patients with chronic uremia. J Biomed Sci 2002;9:549-560.

8 Liu CS, Ko LY, Lim PS, Kao SH, Wei YH: Biomarkers of DNA damage in patients with end-stage renal disease: mitochondrial DNA mutation in hair follicles. Nephrol Dial Transplant 2001;16:561-565. 
-9 Herbert KE, Mistry Y, Hastings R, Poolman T, Niklason L, Williams B: Angiotensin IImediated oxidative DNA damage accelerates cellular senescence in cultured human vascular smooth muscle cells via telomere-dependent and independent pathways. Circ Res 2008;102:201-208.

10 Li H, Mitchell JR, Hasty P: DNA doublestrand breaks: a potential causative factor for mammalian aging? Mech Ageing Dev 2008; 129:416-424.

- 11 Martinet W, Knaapen MW, De Meyer GR, Herman AG, Kockx MM: Elevated levels of oxidative DNA damage and DNA repair enzymes in human atherosclerotic plaques. Circulation 2002;106:927-932.

12 Mercer J, Mahmoudi M, Bennett M: DNA damage, p53, apoptosis and vascular disease. Mutat Res 2007;621:75-86.

13 Loft S, Poulsen HE: Cancer risk and oxidative DNA damage in man. J Mol Med 1996; 74:297-312.

14 Ames BN: Endogenous oxidative DNA damage, aging, and cancer. Free Radic Res Commun 1989;7:121-128.

-15 Hagmar L, Stromberg U, Bonassi S, Hansteen IL, Knudsen LE, Lindholm C, Norppa H: Impact of types of lymphocyte chromosomal aberrations on human cancer risk: results from Nordic and Italian cohorts. Cancer Res 2004;64:2258-2263.

-16 Bonassi S, Znaor A, Ceppi M, Lando C, Chang WP, Holland N, Kirsch-Volders M, Zeiger E, Ban S, Barale R, Bigatti MP, Bolognesi C, Cebulska-Wasilewska A, Fabianova E, Fucic A, Hagmar L, Joksic G, Martelli A, Migliore L, Mirkova E, Scarfi MR, Zijno A, Norppa $H$, Fenech $M$ : An increased micronucleus frequency in peripheral blood lymphocytes predicts the risk of cancer in humans. Carcinogenesis 2007;28: 625-631.

-17 Botto N, Rizza A, Colombo MG, Mazzone AM, Manfredi S, Masetti S, Clerico A, Biagini A, Andreassi MG: Evidence for DNA damage in patients with coronary artery disease. Mutat Res 2001;493:23-30.

18 Maisonneuve P, Agodoa L, Gellert R, Stewart $\mathrm{JH}$, Buccianti G, Lowenfels AB, Wolfe RA, Jones E, Disney AP, Briggs D, McCredie M, Boyle P: Cancer in patients on dialysis for end-stage renal disease: an international collaborative study. Lancet 1999;354:93-99.

-19 Teschner M, Garte C, Rückle-Lanz H, Mader U, Stopper H, Klassen A, Heidland A: Incidence and spectrum of malignant disease among dialysis patients in North Bavaria (in German). Dtsch Med Wochenschr 2002;127: 2497-2502.

-20 Herzog CA, Ma JZ, Collins AJ: Poor longterm survival after acute myocardial infarction among patients on long-term dialysis. $\mathrm{N}$ Engl J Med 1998;339:799-805.

-21 Malachi T, Zevin D, Gafter U, Chagnac A, Slor H, Levi J: DNA repair and recovery of RNA synthesis in uremic patients. Kidney Int 1993;44:385-389.
22 Morena M, Cristol JP, Senecal L, Leray-Moragues $\mathrm{H}$, Krieter $\mathrm{D}$, Canaud $\mathrm{B}$ : Oxidative stress in hemodialysis patients: is NADPH oxidase complex the culprit? Kidney Int Suppl 2002;80:109-114.

23 Fink K, Brink A, Vienken J, Heidland A, Stopper H: Homocysteine exerts genotoxic and antioxidative effects in vitro. Toxicol In Vitro 2007;21:1402-1408.

24 Muller C, Eisenbrand G, Gradinger M, Rath T, Albert FW, Vienken J, Singh R, Farmer PB, Stockis JP, Janzowski C: Effects of hemodialysis, dialyser type and iron infusion on oxidative stress in uremic patients. Free Radic Res 2004;38:1093-1100.

-25 Bagatini PB, Palazzo RP, Rodrigues MT, Costa $\mathrm{CH}$, Maluf SW: Induction and removal of DNA damage in blood leukocytes of patients with type 2 diabetes mellitus undergoing hemodialysis. Mutat Res 2008;657:111115.

26 Herman M, Ori Y, Chagnac A, Korzets A, Weinstein T, Malachi T, Gafter U: Spontaneous DNA repair increases during hemodialysis. Nephron Clin Pract 2008;108:c188-c193.

27 Stopper H, Schupp N, Bahner U, Sebekova K, Klassen A, Heidland A: Genomic damage in end-stage renal failure: potential involvement of advanced glycation end products and carbonyl stress. Semin Nephrol 2004;24:474-478.

28 Schupp N, Schinzel R, Heidland A, Stopper $\mathrm{H}$ : Genotoxicity of advanced glycation end products: involvement of oxidative stress and of angiotensin II type 1 receptors. Ann N Y Acad Sci 2005;1043:685-695.

29 Schupp N, Schmid U, Rutkowski P, Lakner U, Kanase N, Heidland A, Stopper H: Angiotensin II-induced genomic damage in renal cells can be prevented by angiotensin II type 1 receptor blockage or radical scavenging. Am J Physiol 2007;292:F1427-F1434.

-30 Saez GT, Tormos C, Giner V, Chaves J, Lozano JV, Iradi A, Redon J: Factors related to the impact of antihypertensive treatment in antioxidant activities and oxidative stress byproducts in human hypertension. Am J Hypertens 2004;17:809-816.

31 Tepel M: Oxidative stress: does it play a role in the genesis of essential hypertension and hypertension of uraemia? Nephrol Dial Transplant 2003;18:1439-1442.

32 De Cavanagh EM, Ferder L, Carrasquedo F, Scrivo D, Wassermann A, Fraga CG, Inserra F: Higher levels of antioxidant defenses in enalapril-treated versus non-enalapril-treated hemodialysis patients. Am J Kidney Dis 1999;34:445-455.

- 33 Takahashi A, Takase H, Toriyama T, Sugiura T, Kurita Y, Ueda R, Dohi Y: Candesartan, an angiotensin II type-1 receptor blocker, reduces cardiovascular events in patients on chronic haemodialysis - a randomized study. Nephrol Dial Transplant 2006;21: 2507-2512.

34 Efrati S, Zaidenstein R, Dishy V, Beberashvili I, Sharist M, Averbukh Z, Golik A, Weissgarten J: ACE inhibitors and survival of hemodialysis patients. Am J Kidney Dis 2002;40:1023-1029.
35 Fenech M: The in vitro micronucleus technique. Mutat Res 2000;455:81-95.

36 Kan E, Undeger U, Bali M, Basaran N: Assessment of DNA strand breakage by the alkaline comet assay in dialysis patients and the role of vitamin E supplementation. Mutat Res 2002;520:151-159.

37 Schupp N, Dette EM, Schmid U, Bahner U, Winkler M, Heidland A, Stopper H: Benfotiamine reduces genomic damage in peripheral lymphocytes of hemodialysis patients. Naunyn Schmiedebergs Arch Pharmacol 2008;378:283-291.

-38 Stopper H, Treutlein AT, Bahner U, Schupp N, Schmid U, Brink A, Perna A, Heidland A: Reduction of the genomic damage level in haemodialysis patients by folic acid and vitamin $B_{12}$ supplementation. Nephrol Dial Transplant 2008;23:3272-3279.

- 39 Fragedaki E, Nebel M, Schupp N, Sebekova K, Volkel W, Klassen A, Pischetsrieder M, Frischmann M, Niwa T, Vienken J, Heidland A, Stopper H: Genomic damage and circulating age levels in patients undergoing daily versus standard haemodialysis. Nephrol Dial Transplant 2005;20:1936-1943.

40 Schmid U, Stopper H, Schweda F, Queisser N, Schupp N: Angiotensin II induces DNA damage in the kidney. Cancer Res 2008;68: 9239-9246.

41 Dohi Y, Ohashi M, Sugiyama M, Takase H, Sato K, Ueda R: Candesartan reduces oxidative stress and inflammation in patients with essential hypertension. Hypertens Res 2003; 26:691-697.

42 Fliser D, Buchholz K, Haller H: Anti-inflammatory effects of angiotensin II subtype 1 receptor blockade in hypertensive patients with microinflammation. Circulation 2004; 110:1103-1107.

43 Derosa G, Maffioli P, Salvadeo SA, Ferrari I, Gravina A, Mereu R, Palumbo I, D’Angelo A, Cicero AF: Candesartan effect on inflammation in hypertension. Hypertens Res 2010;33: 209-213.

44 Graninger M, Reiter R, Drucker C, Minar E, Jilma B: Angiotensin receptor blockade decreases markers of vascular inflammation. J Cardiovasc Pharmacol 2004;44:335-339.

45 Tai DJ, Lim TW, James MT, Manns BJ, Tonelli M, Hemmelgarn BR: Cardiovascular effects of angiotensin converting enzyme inhibition or angiotensin receptor blockade in hemodialysis: a meta-analysis. Clin J Am Soc Nephrol 2010;5:623-630.

46 Lever AF, Hole DJ, Gillis CR, McCallum IR, McInnes GT, MacKinnon PL, Meredith PA, Murray LS, Reid JL, Robertson JW: Do inhibitors of angiotensin-I-converting enzyme protect against risk of cancer? Lancet 1998; 352:179-184.

47 Friis S, Sorensen HT, Mellemkjaer L, McLaughlin JK, Nielsen GL, Blot WJ, Olsen $\mathrm{JH}$ : Angiotensin-converting enzyme inhibitors and the risk of cancer: a populationbased cohort study in Denmark. Cancer 2001;92:2462-2470. 